\title{
APLIKASI METODE GEOLISTRIK RESISTIVITAS UNTUK ANALISIS BIDANG GELINCIR DAN STUDI KARAKTERISTIK LONGSORAN DI JALAN RAYA SUBAN BANDAR LAMPUNG
}

\author{
Rahmi Mulyasari ${ }^{1}$, IG Boy Darmawan ${ }^{2}$, Dersan S. Effendi ${ }^{3}$, Sugeng P. Saputro ${ }^{4}$, \\ Hesti $^{5}$, Akroma Hidayatika ${ }^{6}$, Nandi Haerudin ${ }^{7}$ \\ 1,2,3,5,6,7 Jurusan T. Geofisika, Fakultas Teknik Universitas Lampung \\ ${ }^{4}$ Lembaga Ilmu Pengetahuan Indonesia (LIPI) Kebumen
}

\author{
Corresponding author: rahmi.mulyasari@eng.unila.ac.id \\ Manuscript received: Feb 06 ${ }^{\text {th }}, 2020$, revised : Feb 08 ${ }^{\text {th }}, 2020$; \\ Approved: Mar 11 th 2020; Available online : Mar 20 ${ }^{\text {th }}, 2020$
}

\begin{abstract}
Abstrak - Kelurahan Pidada, Kecamatan Panjang, Bandar Lampung merupakan daerah yang memiliki potensi gerakan tanah/longsor menengah-tinggi. Salah satu titik langganan kejadian longsor saat hujan berlokasi di Jalan Raya Suban. Keterdapatan bidang gelincir di bawah permukaan tanah yang jenuh air merupakan salah satu penyebab longsoran yang dipicu hujan. Pada penelitian ini, telah dilakukan analisis bidang gelincir dengan metode Resistivitas 2D Konfigurasi Wenner-Schlumberger dan penentuan karakteristik longsoran di Jalan Raya Suban. Berdasarkan hasil penelitian diindikasikan litologi bawah permukaan terdiri atas lapisan sedimen tuff, pasir lempungan dan breksi. Bidang gelincir diperkirakan berada di batas antara lapisan sedimen tuff dan pasir lempungan pada kedalaman (5-15) meter dari permukaan tanah. Hasil analisis dan pengamatan menunjukkan bahwa jenis longsoran yang terjadi merupakan longsoran translasi tanah berbutir halus. Jenis perkuatan lereng yang dapat diterapkan adalah teknik sipil dan vegetatif.
\end{abstract}

\begin{abstract}
Pidada Urban Village, Panjang District, Bandar Lampung is an area that has medium to high landslide potential. One of landslides prone area triggered by rain located on Jalan Raya Suban. The slip surface areas under water-saturated soil is one of causes of landslides triggered by rain. Geophysical method used to detect slip surface is 2D Resistivity Method of Wenner-Schlumberger Configuration. In this study, an analysis of the slip surface has been carried out with the 2D resistivity method of the WennerSchlumberger Configuration and determination characteristic of landslide on Jalan Raya Suban. Based on the results of study indicated that the subsurface lithology consists of layers of tuff sediment, sandy clay and breccia. The slip surface is estimated at the boundary the layers of tuff sediment layer and sandy clay with depth (5-15) meters from the ground surface. The results of analysis and observation showed that type of landslide is translational fine-grained soil. Types of slope reinforcement that can be applied are civil and vegetative techniques.
\end{abstract}

Keywords - slip surface; landslide; resistivity

How to cite this article:

Mulyasari, R., Darmawan, I.G.B., Effendi, D.S., Saputro, S.P., Hesti, Hidayatika, A., dan Haerudin, N., 2020, Aplikasi Metode Geolistrik Resistivitas untuk Analisis Bidang Gelincir dan Studi Karakteristik Longsoran di Jalan Raya Suban Bandar Lampung, Jurnal Geofisika Eksplorasi, 6 (1) p.66-76. doi: 10.23960/jge.v6i1.61

\section{PENDAHULUAN}

Kecamatan Panjang, Bandar Lampung merupakan daerah yang kondisi morfologinya berupa perbukitan dengan kelerengan yang curam, daerah ini diidentifikasi termasuk ke dalam satuan geomorfologi Perbukitan Struktural Tarahan yang dipengaruhi oleh struktur geologinya (Mulyasari dkk., 2019). Bencana alam tanah longsor atau gerakan tanah sering terjadi di wilayah Kecamatan Panjang. Berdasarkan data dari Pusat Vulkanologi 
dan Mitigasi Bencana (PVMBG) pada bulan Januari-Oktober 2019 (PVMBG, 2019), Kecamatan Panjang memiliki potensi gerakan tanah menengah-tinggi.

Curah hujan yang tinggi pada Minggu, 24 Februari 2019 mengguyur Kecamatan Panjang khususnya di Kelurahan Pidada mengakibatkan terjadinya bencana longsor di beberapa titik, salah satunya yang berlokasi di Jalan Raya Suban. Longsor berasal dari tebing bukit Suban yang tidak mampu menahan guyuran hujan. Akibatnya, akses jalan terhambat. Daerah tersebut merupakan daerah langganan kejadian longsor (Harian Lampung, 2019).

Longsor merupakan bencana yang terjadi dipengaruhi oleh faktor morfologi, litologi, struktur geologi, hidrogeologi dan penggunaan lahan. Syarat terjadi longsoran adalah kelerengan yang cukup curam, adanya bidang gelincir di bawah permukaan tanah yang jenuh air dan banyaknya kandungan air yang berasal dari air hujan yang meresap ke dalam tanah.

Salah satu metode geofisika yang dapat mendeteksi bidang gelincir adalah metode Resistivitas 2D Konfigurasi Wenner-Schlumberger (Sugito dkk., 2010). Metode ini dapat dimanfaatkan untuk survei daerah rawan longsor, khususnya untuk menentukan ketebalan lapisan yang berpotensi longsor serta litologi perlapisan batuan di bawah permukaan.

Identifikasi bidang gelincir dan struktur lapisan bawah permukaan pada daerah rawan longsor Jalan Raya Suban, Kecamatan Panjang dilakukan sebagai upaya penentuan karakteristik longsoran dan rekomendasi mitigasi bencana. Identifikasi ini memanfaatkan metode geolistrik resistivitas dengan konfigurasi Wenner-Schlumberger.

\section{TINJAUAN PUSTAKA}

\subsection{Geologi Daerah Penelitian}

Daerah Penelitian berada di Bandar Lampung, yang secara fisiografi berada pada fisiografi Bukit Barisan, adapun berdasarkan morfologinya termasuk ke dalam morfologi daerah pantai berbukit sampai datar. Stratigrafi daerah Penelitian beradasarkan Peta Geologi Lembar Tanjungkarang, termasuk ke dalam batuan produk gunung api Formasi Tarahan (Tpot) yaitu berupa tuf padu, breksi dengan sisipan rijang, Formasi Campang (Tpoc) bagian bawah terdiri dari perselingan batulempung, serpih dan tuf padu, bagian atas terdiri dari breksi aneka bahan dengan sisipan batupasir dan batulanau dan Sekis Way Galih (Pzgs) yang terdiri dari sekis amfibolit hijau, amfibolit ortogenes dioritan. Adapun dari struktur geologinya, daerah penelitian dilalui oleh Sesar Lampung-Panjang yang telah diidentifikasi pada Peta Geologi Lembar Tanjungkarang berarah NW-SE (Mangga dkk., 1993) (Gambar 1).

\subsection{Gerakan Massa/Longsoran}

Varnes (1978 dalam Karnawati 2005) mendefinisikan gerakan massa atau longsoran sebagai gerakan material penyusun lereng kearah bawah atau keluar lereng dibawah pengaruh gravitasi bumi. Menurut Cruden (1991) dalam Karnawati (2005), gerakan massa adalah perpindahan suatu massa batuan, tanah, atau bahan rombakan material penyusun lereng menuruni lereng. Karnawati (2005) menyebutkan, gerakan massa sebagai gerakan menuruni atau keluar lereng oleh massa tanah atau batuan penyusun lereng, ataupun pencampuran keduanya sebagai bahan rombakan, akibat gangguan kestabilan tanah atau ba 
-tuan penyusun lereng tersebut (Tabel 1).

Proses bergeraknya massa tanah atau batuan pada lereng (longsoran) dapat disebabkan oleh adanya pengaruh dari faktor-faktor seperti faktor morfologi, litologi, struktur geologi, hidrogeologi dan penggunaan lahan. Kriteria terjadinya longsoran adalah kelerengan yang cukup curam, terdapatnya bidang gelincir di bawah permukaan tanah yang jenuh air dan banyaknya kandungan air yang berasal dari air hujan yang meresap ke dalam tanah. Kandungan air di dalam tanah dapat mengganggu kestabilan lereng, karena tanah menjadi licin dan tanah pelapukan yang berada di atasnya akan bergerak mengikuti lereng.

\section{METODE PENELITIAN}

Penelitian ini dilaksanakan di Jalan Raya Suban, Kelurahan Pidada, Kecamatan Panjang, Kota Bandar Lampung yang mengalami longsor pada 24 Februari 2019. Longsoran tersebut,a menyebabkan tanah di wilayah perbukitan turun dan menutupi akses jalan. Metode yang digunakan adalah metode geolistrik resistivitas untuk mengukur resistivitas batuan dan mineral. Pada batuan dengan komposisi yang bermacaam-macam akan menghasilkan range nilai resistivitas yang bervariasi dikarenakan oleh jenis tanah dan batuan yang berbeda (Tabel 2) (Telford dkk., 1990).

Pada penelitian ini digunakan konfigurasi Wenner-Schlumberger, konfigurasi ini merupakan gabungan antara pengukuran resistivity mapping (penentuan sebaran lapisan tanah secara horizontal) menggunakan konfigurasi Wenner dan resistivity sounding (penentuan sebaran konduktivitas batuan secara vertikal) menggunakan konfigurasi Schlumberger. Jika dibandingkan dengan konfigurasi
Wenner, konfigurasi Schlumberger mempunyai kedalaman penetrasi $10 \%$ lebih besar (Maganti, 2008 dalam Bukhari dkk., 2017). Ilustrasi titik-titik pengukurannya dapat ditunjukkan pada Gambar 2.

Secara rinci prosedur penelitian dibagi menjadi 3 tahapan, tahapan pertama dari penelitian ini adalah melakukan studi pustaka mengenai geologi daerah penelitian secara regional maupun lokal, peta topografi, peta geomorfologi, peta zonasi potensi area longsor dan data sejarah longsor di zona rawan longsor. Studi pustaka dilakukan untuk mengetahui gambaran umum dan menggali informasi di lokasi penelitian.

Tahapan kedua, dilakukan survei pendahuluan untuk mengetahui gambaran umum dan menggali informasi di lokasi penelitian seperti topografi dan lokasi perumahan penduduk. Hal ini dilakukan untuk membuat desain survei di lokasi yang sesungguhnya, penentuan arah dan panjang lintasan. Posisi dan panjang lintasan untuk pengambilan data sangat menentukan jarak antar elektroda dan posisi penempatan peralatan survei.

Tahapan ketiga, dilakukan pengukuran geolistrik resistivitas 2D. Pengukuran ini menggunakan alat GF Instrumen ARES 3000, serta untuk topografi diperoleh dari data elevasi GPS Garmin 78S sebagai acuan dan pengukuran manual pertitik dengan Jacob Staff.

Lintasan pengukuran terletak di tepi Jalan Raya Suban dengan arah melintang ke arah timur laut. Titik 0 pengukuran terletak pada koordinat E 535719 dan N 9396475 pada elevasi $65 \mathrm{mdpl}$ dan titik akhir dengan bentangan $115 \mathrm{~m}$ dengan spasi elektroda 5 meter, terletak pada koordinat E 535816 dan N 9396510 pada elevasi $105 \mathrm{mdpl}$. Target penetrasi untuk bidang gelincirnya sekitar 15 meter. Peta pengukuran tersebut disajikan pada Gambar 3. Data pengukuran lapangan berupa data tahanan jenis tersimpan 
otomatis di GF Instrumen ARES 3000. Data ini selanjutnya diolah menggunakan Microsoft Excel untuk mendapatkan nilai resistivitas semu ( $\rho$ semu) kemudian dilakukan proses inversi menggunakan software Res2Dinv.

Interpretasi data dilakukan dengan melihat karakteristik batuan yang diperoleh di lapangan serta nilai resistivitas yang diperoleh dari hasil pemodelan inverse least square dengan software Res2Dinv. Interpretasi dilakukan dengan mengkorelasikan penampang 2D hasil pengolahan data software Res2Dinv dengan topograpi daerah penelitian, serta data geologi yang diperoleh dari Peta Geologi Lembar Tanjungkarang. Data yang dihasilkan dari pemodelan ini berupa informasi nilai tahanan jenis bawah permukaan, ketebalan material bawah permukaan, litologi penyusun, serta topografi daerah penelitian.

\section{HASIL DAN PEMBAHASAN}

Temuan signifikan dari penelitian ini adalah dan tebal sedimen di lokasi potensi longsor. Hasil ini menjadi petunjuk analisis upaya mitigasi yang dapat dilakukan untuk mengurangi risiko tanah longsor di Jalan Raya Suban. Berdasarkan studi pustaka dan sejarah kejadian longsor, Jalan Raya Suban cukup sering mengalami longsor. Longsoran tersebut, menyebabkan tanah di wilayah perbukitan turun dan menutupi akses jalan. Kondisi ini terlihat jelas seperti yang disajikan pada Gambar 4 dan Gambar 5.

\subsection{Hasil Pemodelan 2D Resistivitas}

Hasil pemodelan menggunakan metode inversi 2D menghasilkan model inversi tahanan jenis yang disajikan pada Gambar 5. Hasil ini menunjukkan pola bidang gelincir yang cukup tegas.

Berdasarkan pengamatan di lapangan, Tabel 2 (Telford, 1990) mengenai nilai resistivitas batuan dan mineral serta data dari Peta Geologi Daerah Penelitian (Mangga dkk., 1993), lintasan dapat dibagi menjadi 3 lapisan yang berpola resistivitas rendah, menengah dan tinggi (Tabel 3). Pola resistivitas rendah ditunjukkan dengan citra pada pemodelan berwarna biru tuabiru muda dengan harga resistivitas 1-91 $\Omega m$ berada di dekat permukaan dengan karakteristik sangat mudah mengalami longsoran, menunjukkan keberadaan batuan produk gunung api diduga berupa tuff lempungan dan tuff pasiran (sedimen tuff) dari Formasi Tarahan.

Daerah dengan pola resistivitas menengah ditunjukkan dengan citra pada pemodelan berwarna biru langit sampai hijau muda dengan harga resistivitas 91$250 \Omega \mathrm{m}$ diduga berupa batuan vulkanik yang lebih padu, pasir lempungan dari Formasi Campang. Pola resistivitas tinggi ditunjukkan dengan citra pada pemodelan berwarna hijau pekat sampai ungu tua dengan harga resistivitasnya $>250 \Omega \mathrm{m}$ diduga berupa breksi (breccia) dari Formasi Tarahan. Total penetrasi dari pemodelan inversi tahanan jenis pada lintasan pengukuran mencapai $24 \mathrm{~m}$ dengan iterasi 5 menghasilkan nilai root mean square error $18 \%$.

Dari hasil analisis sementara berdasarkan data permukaan dan data sekunder, maka dapat diinterpretasikan nilai sebaran resistivitas bawah permukaan di daerah penelitian. Ketebalan sedimen tuff yang sangat dalam hingga mencapai kedalaman 0-20 $\mathrm{m}$ terdapat pada lintasan $0-45 \mathrm{~m}$, serta lapisan sedimen tuff yang relatif tipis dengan kedalaman 0-3 m pada lintasan kisaran 45-90 m, kemudian terdapat lapisan tuff yang relatif tebal dengan kedalaman 0-18 m pada kisaran lintasan 90-115 m.

Bidang gelincir pada lintasan pengukuran (ditunjukkan dengan garis putus-putus merah) diindikasikan berada di antara lapisan sedimen tuff dan pasir 
lempungan (Gambar 5). Bidang gelincir diperkirakan berada pada kedalaman (515) meter dari permukaan tanah. Lapisan-lapisan yang berada di atas bidang gelincir diduga sebagai lapisan batuan lapuk atau zona rawan longsor yang dapat menjadi zona tersaturasi air.

Berdasarkan pemodelan lapisan dapat diidentifikasi bahwa lapisan ini memiliki kontras nilai tahanan jenis yang relatif dangkal pada panjang lintasan kisaran 45-90 m. Kondisi tersebut memicu terjadinya longsoran karena pada lapisan ini didominasi oleh sedimen tuff, yang di bagian bawah lintasan terdapat zona tersaturasi air pada kedalaman $5 \mathrm{~m}$. Volume sedimen tuff yang relatif kecil dan terletak di atas lereng tidak telalu berdampak pada kerusakan yang tinggi, namun memiliki risiko yang tinggi pada bagian bawah lintasan karena bersinggungan langsung dengan Jalan Kelurahan Pidada yaitu Jalan Raya Suban.

Daerah penelitian merupakan daerah rawan longsor yang memiliki tingkat kerawanan yang tinggi, dibuktikan dengan daerah tersebut memiliki struktur bawah tanah yang dominan dengan sedimen tuff dan pasir lempungan, dengan ketebalan sedimen diperkirakan mencapai $15 \mathrm{~m}$ dan didukung faktor geografis yang menunjukkan kemiringan lereng $>30^{\circ}$.

\subsection{Analisis Karakteristik Longsor dan Rekomendasi Teknik Mitigasi}

Hasil analisis dan pengamatan menunjukkan bahwa jenis longsoran yang terjadi merupakan longsoran tanah butir halus (slide) tipe translasi (Tabel 1) (Karnawati, 2005). Berdasarkan analisis geolistrik, sedimen berbutir halus yang mengalami longsoran adalah sedimen tuff dan pasir lempungan. Bidang gelincir berada di antara sedimen tuff dan pasir lempungan. Longsoran yang terjadi dipengaruhi oleh faktor morfologi dengan kelerengan yang curam $\left(>30^{\circ}\right)$, kondisi litogi yang berupa sedimen lepas yang rawan longsor, dan hidrogeologi yang dipengaruhi oleh curah hujan dan kondisi drainase yang belum tertata dengan baik.

Berdasarkan peta tata guna lahan, daerah penelitian berada pada penggunaan lahan pemukiman. Pada Tabel 4, Paimin dkk. (2009), teknik penanggulangan bencana (mitigasi) yang sebaiknya dilakukan jika telah terjadi longsor pada pemukiman adalah dengan Teknik Sipil dan Vegetatif. Upaya pengendalian longsoran metode teknik sipil yaitu pengurugan/penutupan rekahan, reshaping lereng (pembentukan lereng menjadi lebih landai), penguatan lereng terjal dengan bronjong kawat/ tebing penahan, perbaikan drainase, baik drainase permukaan seperti saluran pembuangan air (waterway) maupun drainase bawah tanah. Untuk mengurangi aliran air, drainase bawah tanah dilakukan dengan cara mengalirkan air secara horizontal melalui terowongan air seperti paritan (trench) dan sulingan (pipa perforasi).

Teknik pengendalian longsoran metode vegetatif harus dipilah antara bagian kaki, bagian tengah, dan bagian atas lereng. Stabilisasi tanah diutamakan pada kaki lereng, baik dengan tanaman (vegetatif) maupun bangunan. Persyaratan vegetasi untuk pengendalian tanah longsor antara lain: jenis tanaman memiliki sifat perakaran dalam (mencapai batuan), perakaran rapat dan mengikat agregat tanah, dan bobot biomassanya ringan (Paimin dkk., 2009).

Pada tebing yang rawan longsor, kerapatan tanaman berbeda antara bagian kaki lereng (paling rapat $=$ standar kerapatan tanaman), tengah (agak jarang $=1 / 2$ standar) dan atas (jarang $=1 / 4$ standar). Kerapatan yang jarang diisi dengan tanaman rumput dan atau tanaman penutup tanah (cover crop) dengan drainase baik, seperti pola agroforestry. Pada bagian tengah dan atas lereng diupayakan perbaikan sistem drainase (internal dan eksternal) yang 
baik sehingga air yang masuk ke dalam tanah tidak terlalu besar, agar tingkat kejenuhan air pada tanah yang berada di atas lapisan kedap (bidang gelincir) bisa dikurangi bebannya.

\section{KESIMPULAN DAN SARAN}

Berdasarkan hasil penelitian dengan menggunakan metode geolistrik resistivitas diperoleh hasil signifikan bahwa bidang gelincir berada di antara lapisan breksi dan sedimen tuff. Hasil penelitian juga menunjukkan bahwa struktur bawah permukaan dapat dibagi menjadi 3 lapisan yaitu sedimen tuff dengan nilai tahanan jenis yaitu 1-91 $\Omega \mathrm{m}$, pasir lempungan dengan nilai tahanan jenis yaitu 91-250 $\Omega \mathrm{m}$, dan breksi (breccia) dengan nilai tahanan jenis yaitu $>250 \Omega \mathrm{m}$. Tingkat risiko longsor dibuktikan dengan daerah tersebut memiliki struktur bawah tanah yang dominan dengan tanah lempung, dengan ketebalan sedimen diperkirakan mencapai $15 \mathrm{~m}$ dan didukung faktor geografis yang menunjukkan kemiringan lereng $>30^{\circ}$.

Hasil analisis dan pengamatan menunjukkan bahwa jenis longsoran yang terjadi merupakan longsoran tanah butir halus (slide) tipe translasi. Salah satu jenis perkuatan lereng yang dapat diterapkan adalah teknik sipil dan vegetatif. Longsor terjadi dipengaruhi oleh faktor morfologi dengan kelerengan yang curam, litogi, dan hidrogeologi. Hasil analisis bidang gelincir yang dihasilkan dapat menjadi salah satu panduan mitigasi longsor.

\section{UCAPAN TERIMA KASIH}

Ucapan terima kasih disampaikan kepada Lembaga Penelitian dan Pengabdian (LPPM) Unila yang telah memberikan dana pada kegiatan penelitian pada skema Penelitian Dosen
Pemula (PDP). Selanjutnya, terima kasih juga kepada Pemerintah Daerah Kecamatan Panjang yang telah memberikan izin pada penelitian ini.

\section{DAFTAR PUSTAKA}

Bukhari, Saputra, A. D., Pratama, A. H., Abdullah, F., Yanis, M. dan Ismail, N., 2017, Identifikasi struktur berpotensi longsor berdasarkan model resistivitas listrik 2D, Prosiding Semirata 2017 Bidang MIPA BKS-PTN Wilayah Barat, ISBN: 978-602-50593-0-8, 942-953.

Harian Lampung, 2019, Babinsa Koramil 0410-01 Panjang Bersama Masyarakat Gotong Royong Bersihkan Banjir dan Longsor, http://www.harianlampung.com/inde x.php?k=Politik\&i=49735, diakses 20 November 2019.

Karnawati, D., 2005, Gerakan Massa Tanah di Indonesia dan Upaya Penanggulangannya, Jurusan Teknik Geologi Fakultas Teknik UGM, Yogyakarta.

Mulyasari, R., Utama, H.W., dan Haerudin, N., 2019, Geomorphology study on the Bandar Lampung Capital City for recommendation of development area, IOP Conf. Series: Earth and Environmental Science 279 (2019) 012026.

Paimin, Sukresno danPramono. I. P., 2009, Teknik Mitigasi Banjir dan Tanah Longsor, Tropenbos International Indonesia Programme, Balikpapan.

Pusat Vulkanologi dan Mitigasi Bencana Geologi (PVMBG), 2019, Wilayah Potensi Gerakan Tanah di Lampung, http://www.vsi.esdm.go.id/, diakses tanggal 17 Oktober 2019. 
Sugito, Irayani, Z. dan Jati, I.P., 2010, Investigasi bidang gelincir tanah longsor menggunakan metode geolistrik tahanan jenis di Desa Kebarongan Kec. Kemranjen Kab. Banyumas, Berkala Fisika, ISSN: 1410 - 9662, Vol 13, Ed. 2.

Telford, W. M, Geldard, L.P, Sherrif, R.E., dan Keys, D. A., 1990, Applied Geophysics, Cambridge
University Press, London.

Utiya, J., As'ari dan Tongkukut, HJ., 2015, Metode geolistrik resistivitas konfigurasi Wenner-Schlumberger dan konfigurasi Dipole-Dipole untuk Identifikasi patahan Manado di Kecamatan Paaldua Kota Manado, Jurnal Ilmiah Sains, Vol 15, No 2.

\section{LAMPIRAN}

Tabel 1. Jenis Gerakan Massa (Karnawati, 2005).

\begin{tabular}{|c|c|c|c|c|c|}
\hline \multirow{3}{*}{\multicolumn{3}{|c|}{ JENIS GERAKAN TANAH }} & \multicolumn{3}{|c|}{ JENIS MATERIAL } \\
\hline & & & \multirow{2}{*}{ BATUAN } & \multicolumn{2}{|c|}{ TANAH TEKNIK } \\
\hline & & & & Berbutir Kasar & Berbutir Halus \\
\hline \multicolumn{3}{|c|}{ RUNTUHAN (FALLS) } & $\begin{array}{c}\text { Runtuhan } \\
\text { Batuan }\end{array}$ & $\begin{array}{c}\text { Runtuhan Bahan } \\
\text { Rombakan }\end{array}$ & $\begin{array}{c}\text { Runtuhan } \\
\text { Tanah }\end{array}$ \\
\hline \multicolumn{3}{|c|}{ ROBOHAN (TOPPLES) } & $\begin{array}{c}\text { Robohan } \\
\text { Batuan }\end{array}$ & $\begin{array}{c}\text { Robohan Bahan } \\
\text { Rombakan }\end{array}$ & Robohan Tanah \\
\hline \multirow{3}{*}{$\begin{array}{l}\text { LONGSORA } \\
\mathrm{N}(\text { SLIDES })\end{array}$} & ROTASI & \multirow{2}{*}{$\begin{array}{l}\text { Beberap } \\
\text { a Unit }\end{array}$} & $\begin{array}{c}\text { Nendatan } \\
\text { Batuan }\end{array}$ & $\begin{array}{l}\text { Nendatan Bahan } \\
\text { Rombakan }\end{array}$ & $\begin{array}{l}\text { Nendatan } \\
\text { Tanah }\end{array}$ \\
\hline & \multirow{2}{*}{$\begin{array}{c}\text { TRANSLAS } \\
\text { I }\end{array}$} & & $\begin{array}{l}\text { Longsoran } \\
\text { blok batuan }\end{array}$ & $\begin{array}{l}\text { Longsoran blok } \\
\text { bahan rombakan }\end{array}$ & $\begin{array}{c}\text { Longsoran blok } \\
\text { tanah }\end{array}$ \\
\hline & & $\begin{array}{c}\text { Banyak } \\
\text { Unit }\end{array}$ & $\begin{array}{c}\text { Longsoran } \\
\text { batuan }\end{array}$ & $\begin{array}{c}\text { Longsoran bahan } \\
\text { rombakan }\end{array}$ & $\begin{array}{c}\text { Longsoran } \\
\text { tanah }\end{array}$ \\
\hline \multicolumn{3}{|c|}{$\begin{array}{l}\text { PENCARAN LATERAL } \\
(L A T E R A L S P R E A D S) \\
\end{array}$} & $\begin{array}{c}\text { Pencaran } \\
\text { batuan }\end{array}$ & $\begin{array}{c}\text { Pencaran bahan } \\
\text { rombakan }\end{array}$ & Pencaran tanah \\
\hline \multirow{5}{*}{\multicolumn{3}{|c|}{ ALIRAN (FLOWS) }} & \multirow{5}{*}{$\begin{array}{c}\text { Aliran } \\
\text { batuan } \\
\text { (rayapan } \\
\text { dalam) }\end{array}$} & $\begin{array}{c}\text { Aliran bahan } \\
\text { rombakan }\end{array}$ & $\begin{array}{l}\text { Aliran } \\
\text { pasir/lanau } \\
\text { basah }\end{array}$ \\
\hline & & & & Solifluction & $\begin{array}{l}\text { Aliran pasir } \\
\text { kering }\end{array}$ \\
\hline & & & & $\begin{array}{c}\text { Lawina bahan } \\
\text { rombakan }\end{array}$ & Aliran tanah \\
\hline & & & & $\begin{array}{c}\text { Rayapan bahan } \\
\text { rombakan }\end{array}$ & Aliran lepas \\
\hline & & & & Aliran blok & \\
\hline \multicolumn{3}{|c|}{ KOMPLEKS (COMPLEX) } & \multicolumn{3}{|c|}{ Campuran dari dua (atau lebih) jenis gerakan } \\
\hline
\end{tabular}


Tabel 2. Nilai resistivitas batuan dan mineral (Telford dkk., 1990).

\begin{tabular}{|c|c|}
\hline Material & Harga resistivitas ( M) \\
\hline Air Permukaan & $80-200$ \\
\hline Air Tanah & $30-100$ \\
\hline Silt-lempung & $10-200$ \\
\hline Pasir & $100-600$ \\
\hline Pasir dan Kerikil & $100-1000$ \\
\hline Batu Lumpur & $20-200$ \\
\hline Batu Pasir & $50-500$ \\
\hline Konglomerat & $100-500$ \\
\hline Tufa & $20-200$ \\
\hline Kelompok Adesit & $100-2000$ \\
\hline Kelompok Granit & $1000-10000$ \\
\hline Tanah Lempung & $1,5-3,0$ \\
\hline Lempung Lanau & $3,0-15$ \\
\hline Tanah Lanau Pasiran & $15-150$ \\
\hline Batuan Dasar Lembab & $150-300$ \\
\hline Pasir Kerikil Kelanauan & 300 \\
\hline Batuan Dasar Tak lapuk & 2400 \\
\hline terdapat Air Tawar & $20-60$ \\
\hline Air Asin & $20-200$ \\
\hline Kelompok Chert, Slate & $0,18-0,24$ \\
\hline \multicolumn{2}{|l|}{ Unconsolidated Sedimen } \\
\hline Sand & $1-1000$ \\
\hline Clay & $1-100$ \\
\hline Marl & $1-100$ \\
\hline \multicolumn{2}{|l|}{ Ground Water } \\
\hline Portable well water & $0,1-1000$ \\
\hline Breckish water & $0,3-1$ \\
\hline Sea Water & $0,05-0,2$ \\
\hline
\end{tabular}

Tabel 3. Interpretasi jenis batuan berdasarkan nilai resistivitas.

\begin{tabular}{|c|c|c|l|}
\hline No. & $\begin{array}{c}\text { Warna } \\
\text { Pemodelan }\end{array}$ & $\begin{array}{c}\text { Resistivitas } \\
(\mathbf{\Omega m})\end{array}$ & \multicolumn{1}{|c|}{ Interpretasi Jenis Batuan } \\
\hline 1 & $\begin{array}{c}\text { Biru tua-biru } \\
\text { muda }\end{array}$ & $1-91$ & $\begin{array}{l}\text { Batuan berada pada permukaan yang } \\
\text { memiliki resistivitas relatif rendah dengan } \\
\text { karakteristik sangat mudah mengalami } \\
\text { longsoran. Berdasarkan pengamatan dan } \\
\text { rentang resisitivitas rendah kemungkinan } \\
\text { berasosiasi dengan batuan dengan litologi } \\
\text { tuff lempungan dan tuff pasiran (sedimen } \\
\text { tuff) memiliki kedalaman bervariasi antara } \\
\text { 0-20 meter. }\end{array}$ \\
\hline 2 & $\begin{array}{l}\text { Biru langit - } \\
\text { hijau muda }\end{array}$ & $91-250$ & $\begin{array}{l}\text { Batuan yang diperkirakan dapat berfungsi } \\
\text { sebagai bidang gelincir dengan nilai } \\
\text { resistivitas menengah, diperkirakan berupa } \\
\text { pasir lempungan. }\end{array}$ \\
\hline 3 & Hijau pekat - & $>250$ & $\begin{array}{l}\text { Lapisan keras, massif, porositas buruk dan } \\
\text { tidak dapat menyimpan air di antara pori- } \\
\text { pori batuannya diperkirakan berupa } \\
\text { perpaduan antara breksi padu dengan } \\
\text { komponen batuan beku. }\end{array}$ \\
\hline
\end{tabular}


Tabel 4. Arahan Teknik Penanggulan Bencana Tanah Longsor pada Berbagai Penggunaan Lahan dan Tingkatan Proses Longsor (Paimin dkk., 2009).

\begin{tabular}{|c|c|c|c|c|}
\hline \multirow[t]{2}{*}{ Tingkat longsor } & \multicolumn{4}{|c|}{ Penggunaan Lahan } \\
\hline & Hutan & Tegal & Sawah & Pemukiman \\
\hline Belum longsor & Vegetatif & Vegetatif & Teknik sipil & $\begin{array}{l}\text { Tekn. Sipil \& } \\
\text { Vegetatif }\end{array}$ \\
\hline Retakan/rekahan & $\begin{array}{l}\text { Tekn. Sipil \& } \\
\text { Vegetatif }\end{array}$ & $\begin{array}{l}\text { Tekn. Sipil \& } \\
\text { Vegetatif }\end{array}$ & Teknik sipil & $\begin{array}{l}\text { Tekn. Sipil \& } \\
\text { Vegetatif }\end{array}$ \\
\hline Longsor & $\begin{array}{l}\text { Tekn. Sipil \& } \\
\text { Vegetatif }\end{array}$ & $\begin{array}{l}\text { Tekn. Sipil \& } \\
\text { Vegetatif }\end{array}$ & $\begin{array}{l}\text { Teknik Sipil \& } \\
\text { Vegetatif }\end{array}$ & $\begin{array}{l}\text { Tekn. Sipil \& } \\
\text { Vegetatif }\end{array}$ \\
\hline
\end{tabular}

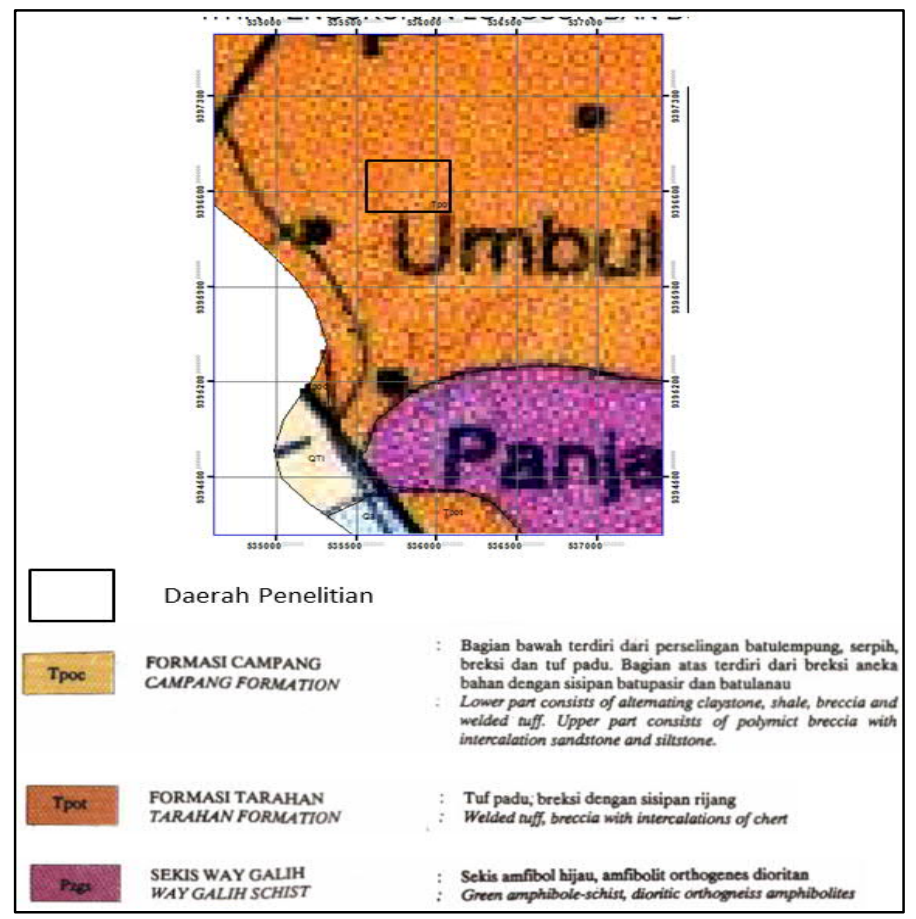

Gambar 1. Peta Geologi Daerah Penelitian (Mangga dkk., 1993).

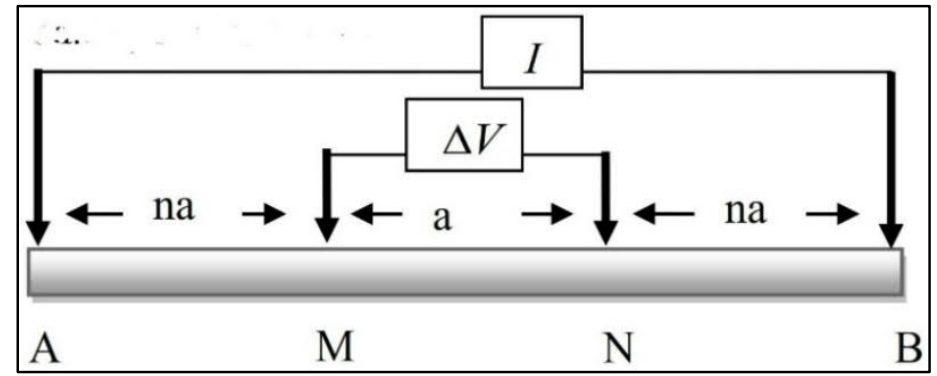

Gambar 2. Ilustrasi titik-titik pengukuran Konfigurasi Wenner-Schlumberger (Utiya dkk., 2015). 


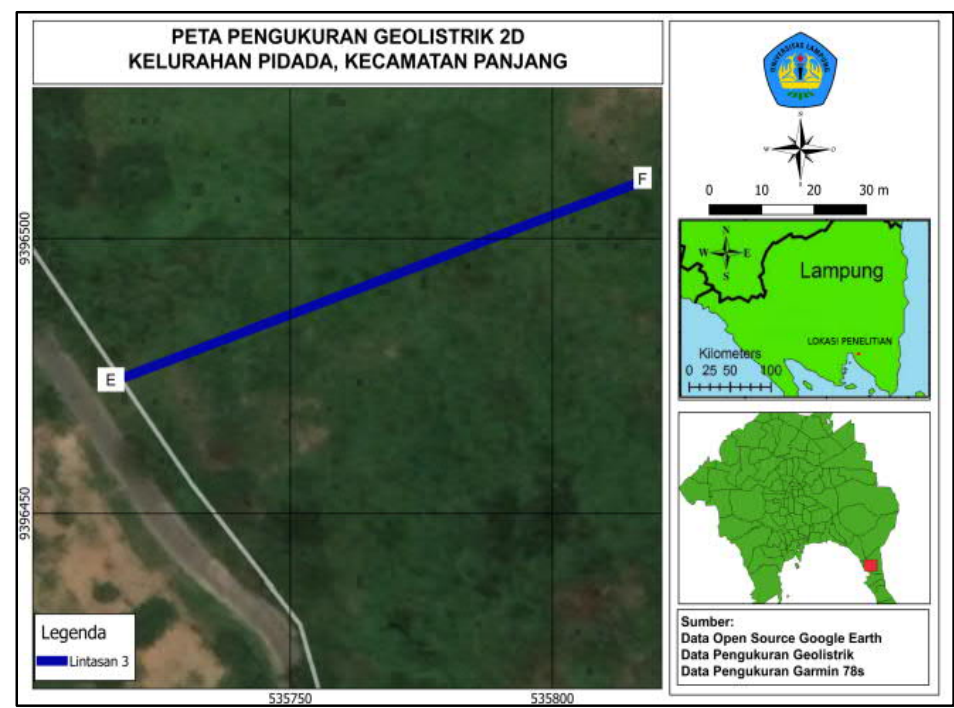

Gambar 3. Peta Pengukuran dan penampang 2D Kelurahan Panjang, Kecamatan Panjang.

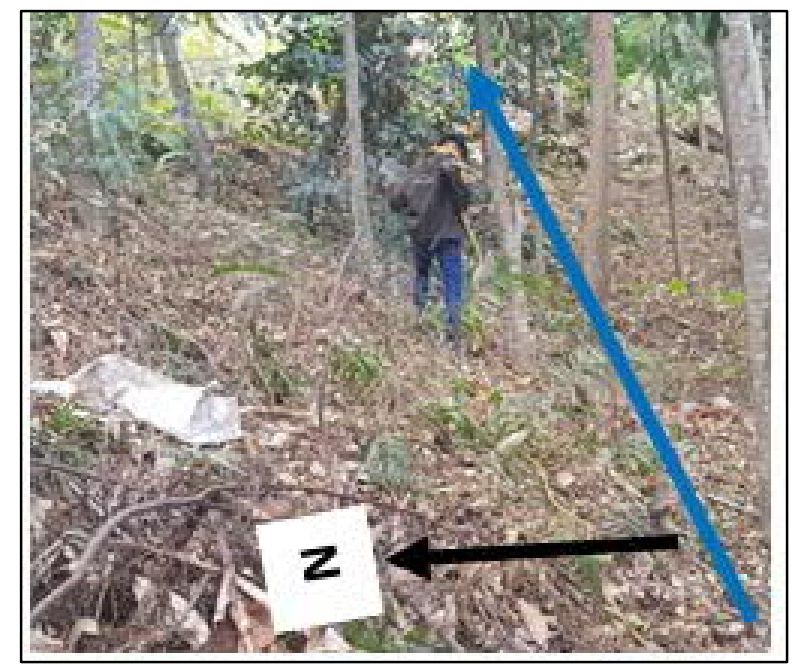

Gambar 4. Visualisasi daerah Penelitian.

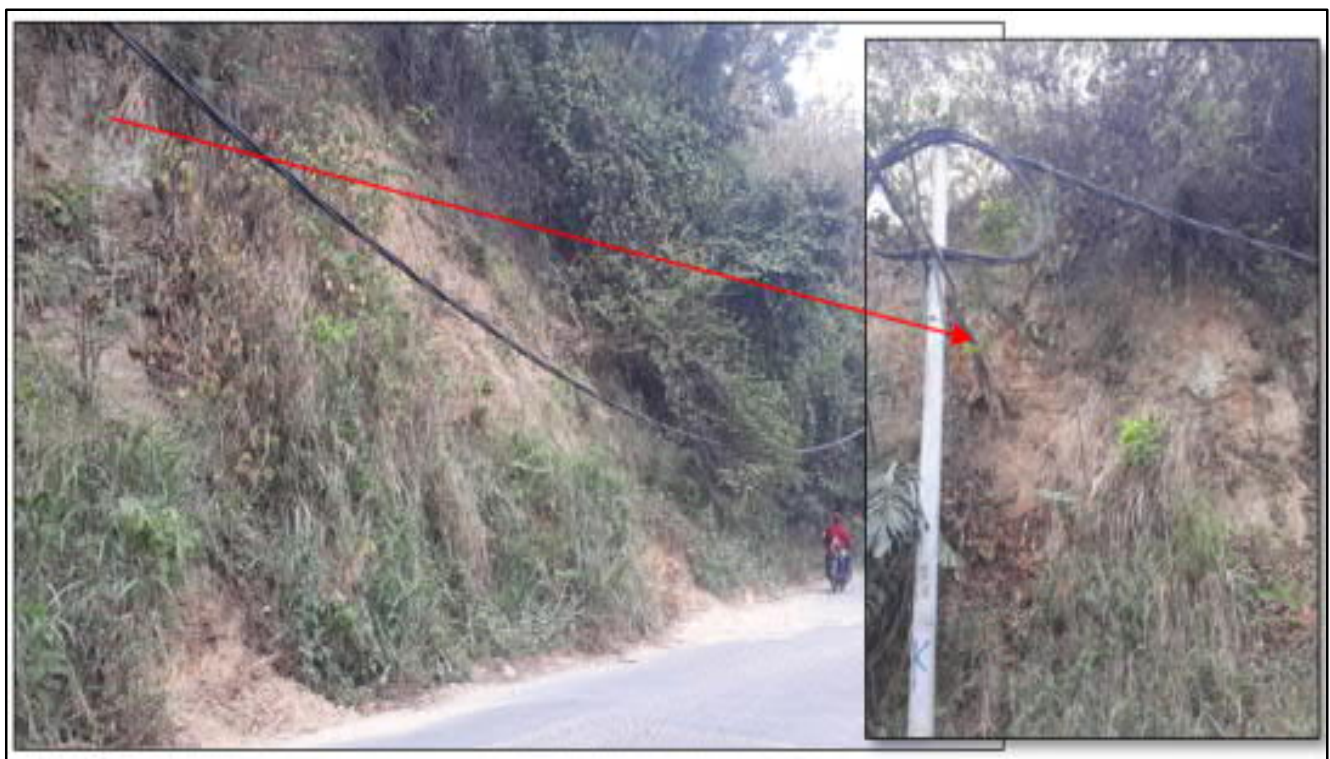

Gambar 5. Lokasi titik longsoran di Jalan Raya Suban, Kelurahan Pidada. 


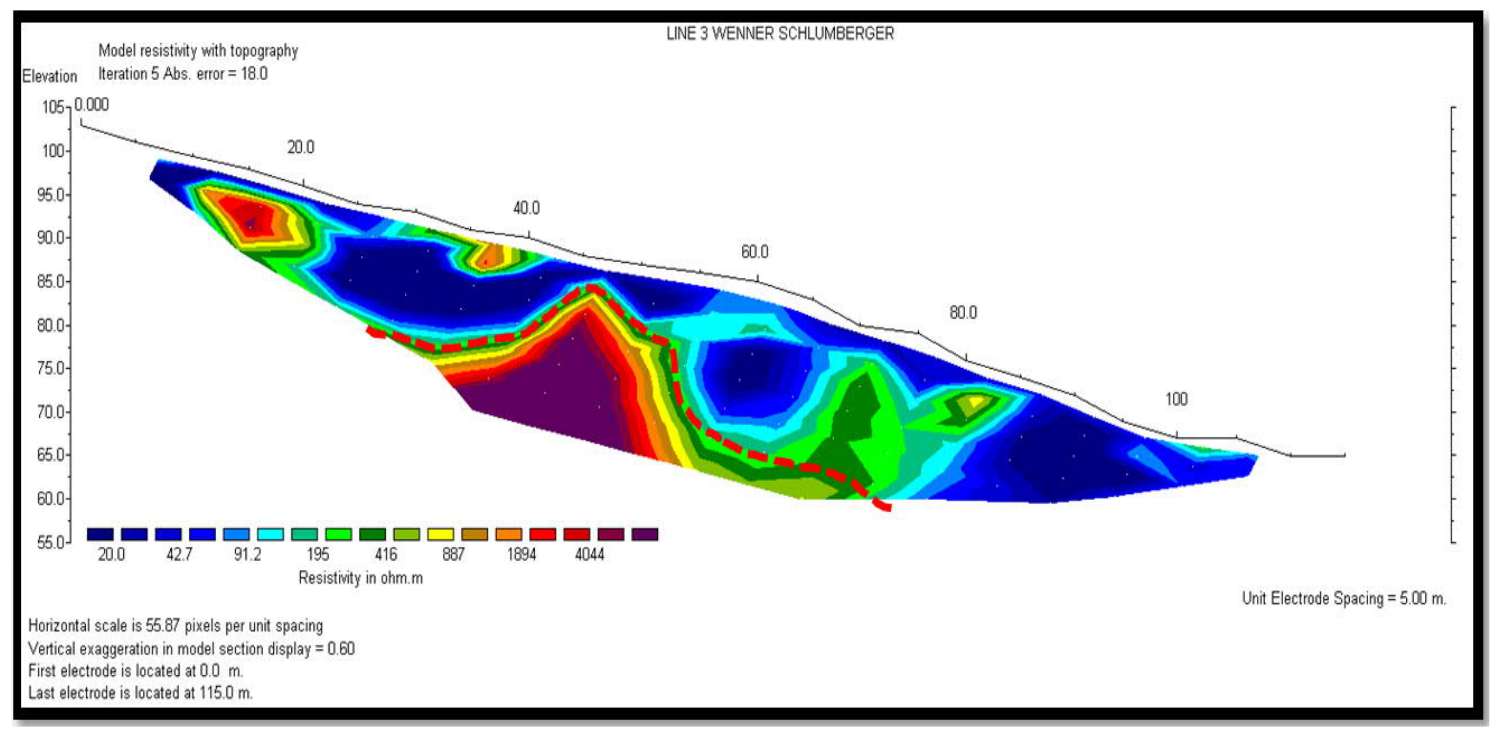

Gambar 6. Penampang melintang Lintasan. 